\title{
First record of Dilaridae (Neuroptera) in the state of Pernambuco, Brazil
}

\author{
Caleb Califre Martins ${ }^{1 *}$ and Alan Pedro de Araújo ${ }^{2}$ \\ 1 Universidade de São Paulo, FFCLRP, Departamento de Biologia, Laboratório de Morfologia e Evolução de Diptera, Av. dos Bandeirantes, \\ 3900, CEP 14040-901, Ribeirão Preto, SP, Brazil \\ 2 Universidade do Estado da Bahia, Campus VIII, Departamento de Educação, Rua do Bom Conselho, 179, CEP 48608-230, Paulo Afonso, \\ BA, Brazil \\ * Corresponding author. E-mail: calebcalifre@gmail.com
}

\begin{abstract}
Dilaridae is a small family of Neuroptera that includes fewer than 80 described species of which 10 are known from Brazil in the states of Amazonas, Rondônia, Rio Grande do Norte, Paraíba, Minas Gerais, Goiás, Mato Grosso do Sul, Rio de Janeiro, São Paulo, Paraná and Santa Catarina. This note includes the first record of the family for the state of Pernambuco, with the report of Nallachius dicolor Adams, 1970 in the city of Jatobá (northeastern Brazil).
\end{abstract}

Key words: Caatinga; Nallachius dicolor; northeastern Brazil; pleasing lacewing

Dilaridae (Pleasing lacewings) is a small group of Neuroptera whose adults have ocelli-like tubercles on the head in both sexes. Females are recognized by their long ovipositor (consisting of the gonocoxites 9) and males by their pectinate antennae, which is not present in females (Grimaldi and Engel 2005; Zhang et al. 2014).

The extant diversity of the family is composed of about 80 species distributed in two subfamilies. Dilarinae contains three genera (Dilar Rambur, Berothella Banks, and Neonallachius Nakahara) with males exhibiting reduced ectoprocts, gonarcus with laterally articulated gonocoxites and two submedially articulated mediuncus lobes (Acker 1960; Adams 1970; Zhang et al. 2014). The subfamily Nallachiinae comprises the genus Nallachius Navás which has males exhibiting well-developed ectoprocts, a median sclerite articulated on the gonarcus, and with gonocoxites and mediuncus similar to those of Dilarinae (Adams 1970; Oswald 1998; Zhang et al. 2014).

Dilarinae species occur in the Palearctic and Oriental regions; Dilar is the predominant genus of this subfamily in Asia and Europe, comprising 47 described species (Zhang et al. 2014). Nallachiinae occurs mostly in the
New World, with one species in Vietnam (Nallachius ponomarenskoi Zakharenko, 1991) and another in southern Africa (Nallachius krooni Minter) (Grimaldi and Engel 2005). The New World diversity of Dilaridae is restricted to 18 species of Nallachius (Nallachiinae), 10 of which are known for Brazil (Table 1) (Oswald 1998; Monserrat 2005).

Among Brazilian species of Dilaridae is Nallachius dicolor Adams, 1970 which has the largest distribution area in Brazil. This species was first collected in Nova Teutônia, state of Santa Catarina (southern Brazil). Machado and Rafael (2010) added new locations of occurrence for this species; three specimens from Caldas Novas, state of Goiás (midwestern Brazil) and four specimens of Berizal, state of Minas Gerais (transition from southeastern to northeastern Brazil). Here we report the first record of $N$. dicolor for the state of Pernambuco (northeastern Brazil).

One male of $N$. dicolor was collected in a light trap on 7 March 2015 in Jatobá $\left(09^{\circ} 10^{\prime} 59^{\prime \prime}\right.$ S, 038 $16^{\prime} 08^{\prime \prime}$ W). This location is within the Caatinga biome, which is endemic to Brazil and occurs in the states of Alagoas, Bahia, Ceará, Maranhão, Pernambuco, Paraíba, Rio Grande

Table 1. Distribution of Brazilian Dilaridae (Neuroptera) species (after Martins and Amorim, 2015, modified).

\begin{tabular}{ll}
\hline Dilaridae species & States of Brazil \\
\hline Nallachius adamsi Penny 1981:385 & Amazonas \\
N. dicolor Adams 1970: 19 & $\begin{array}{l}\text { Pernambuco (new record), Minas } \\
\text { Gerais, Goiás, Santa Catarina }\end{array}$ \\
N. furcatus Machado \& Rafael 2010: 62 & Paraíba \\
N. infuscatus Penny 1981:386 & Amazonas, Rondônia \\
N. limai Adams 1970: 23 & São Paulo, Paraná, Santa Catarina \\
N. maculatus Penny 1981:389 & Rondônia \\
N. ovalis Adams 1970: 17 & Santa Catarina \\
N. phantomellus Adams 1970: 12 & Mato Grosso do Sul \\
N. potiguar Machado \& Rafael 2010: 62 & Rio Grande do Norte \\
N. prestoni (McLachlan 1880):39 & Rio de Janeiro \\
\hline
\end{tabular}


do Norte, Piauí, Sergipe and the northern portion of Minas Gerais, where some of the specimens reported by Machado and Rafael (2010) were collected (Governo do Estado de Pernambuco 2015).

For the examination of genitalia, the abdominal segments were removed and treated with a solution of $10 \%$ potassium hydroxide $(\mathrm{KOH})$ at $40^{\circ} \mathrm{C}$ for $10-15$ minutes. Internal structures were rinsed with distilled water, followed by glycerin injection through the abdominal apex. Genitals were stored in microtubes with glycerin. Photos were taken with a Leica DC 500 camera attached to a Leica M16 stereomicroscope, assembled

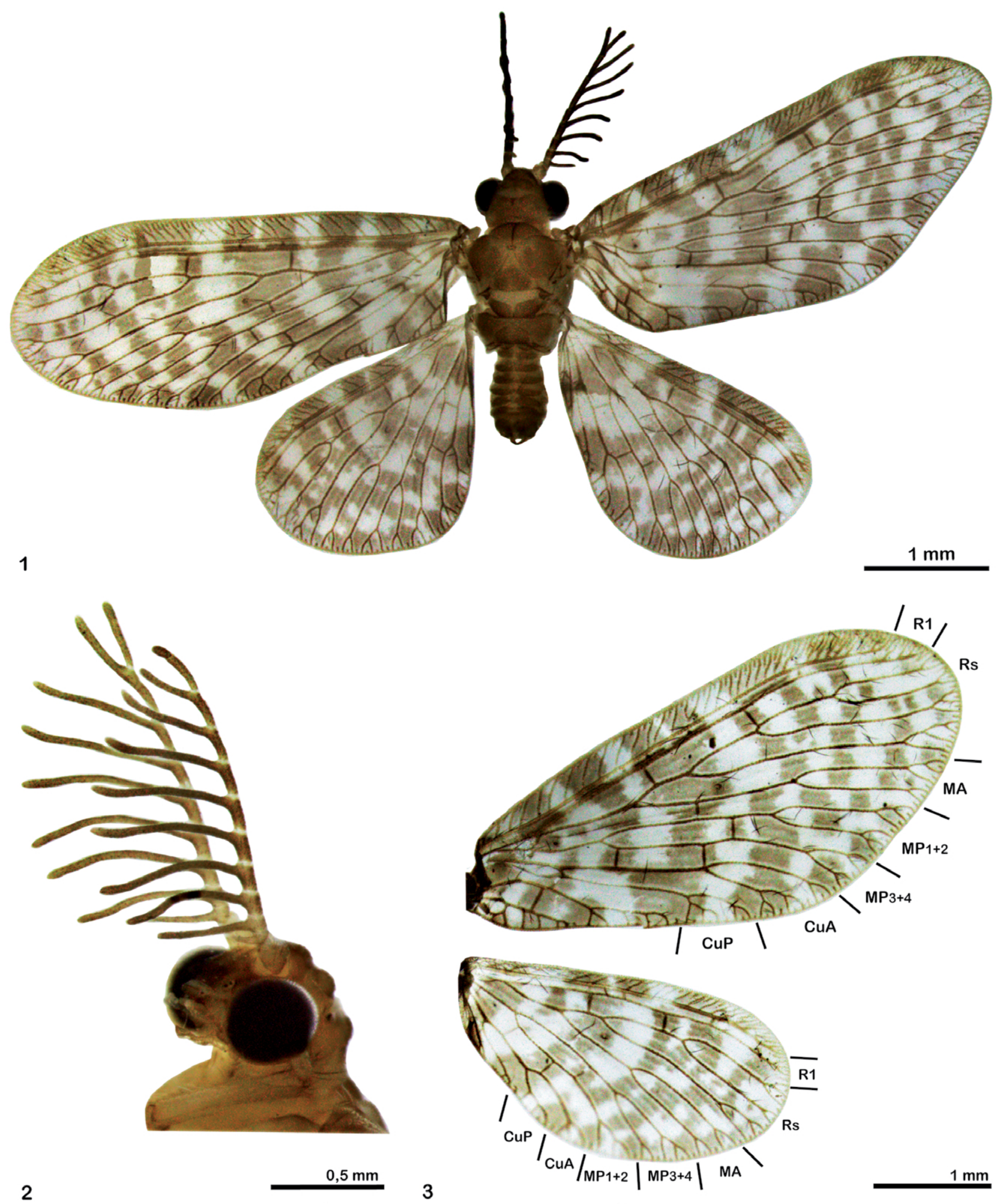

Figures 1-3. Male of Nallachius dicolor Adams, 1970 (Neuroptera: Dilaridae) from Jatobá, state of Pernambuco, northeastern Brazil. 1: Dorsal habitus. 2: Head and antennae, lateral view. 3: Forewing and hindwing. Cubitus anterior (CuA); cubitus posterior (CuP); media anterior (MA); media posterior (MP); radial sector (Rs); radius (R1). 
4
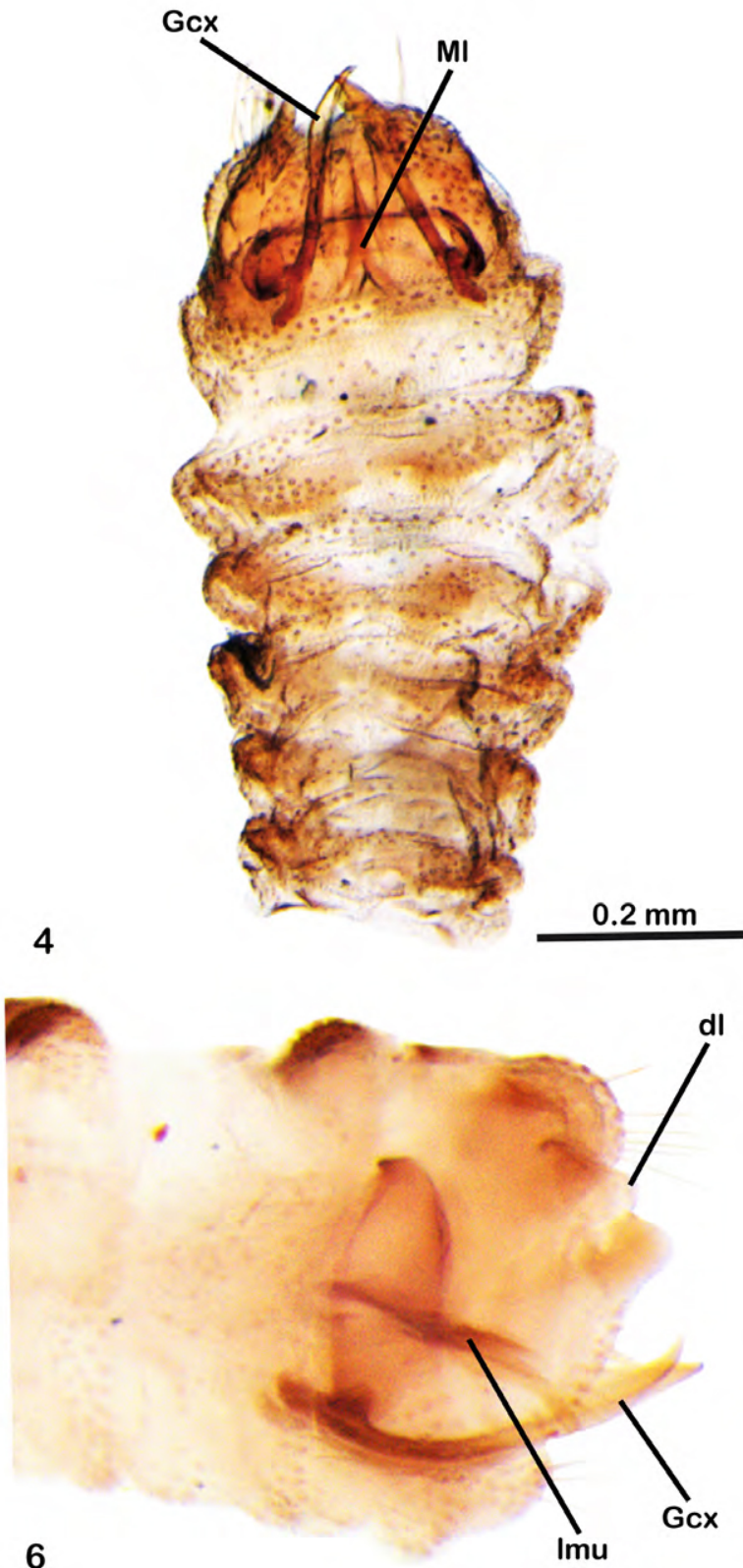

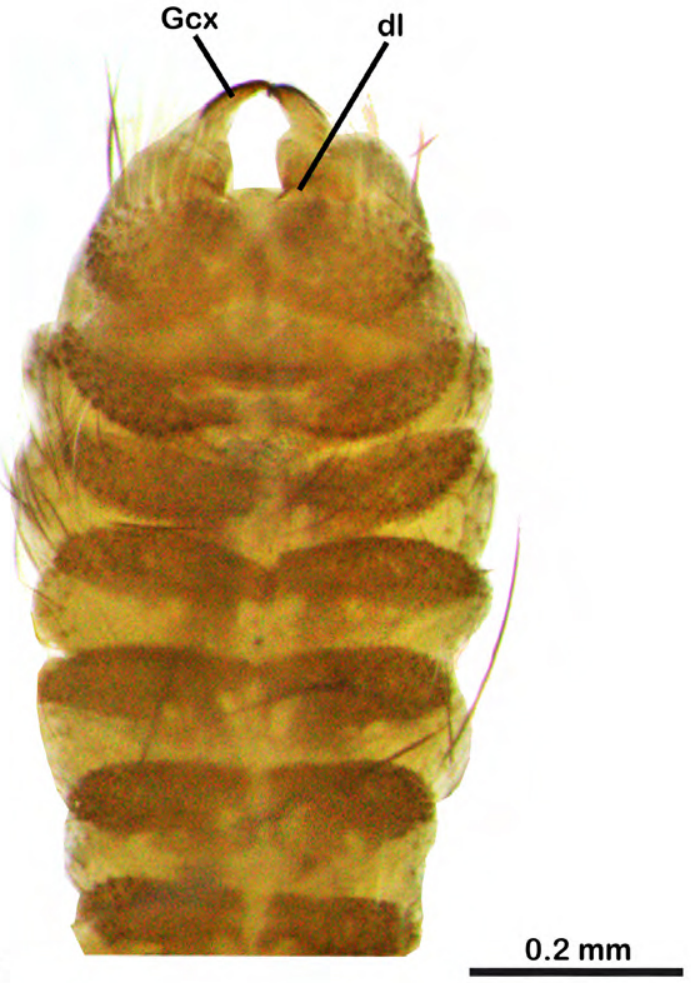

5

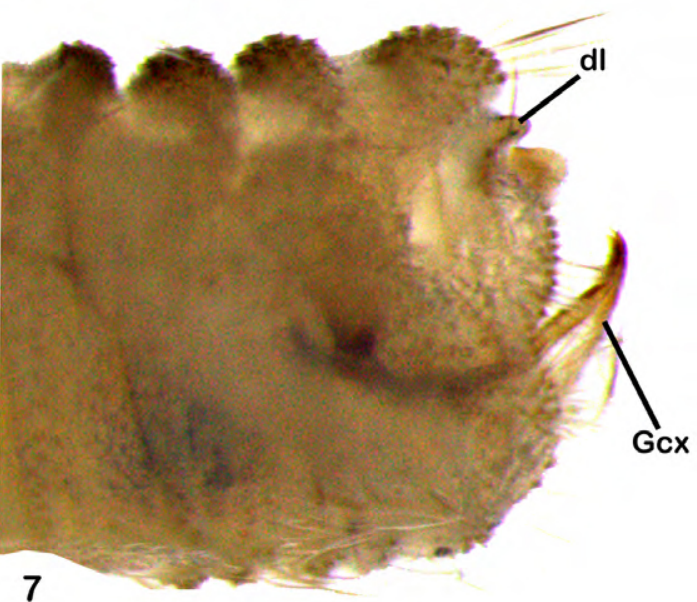

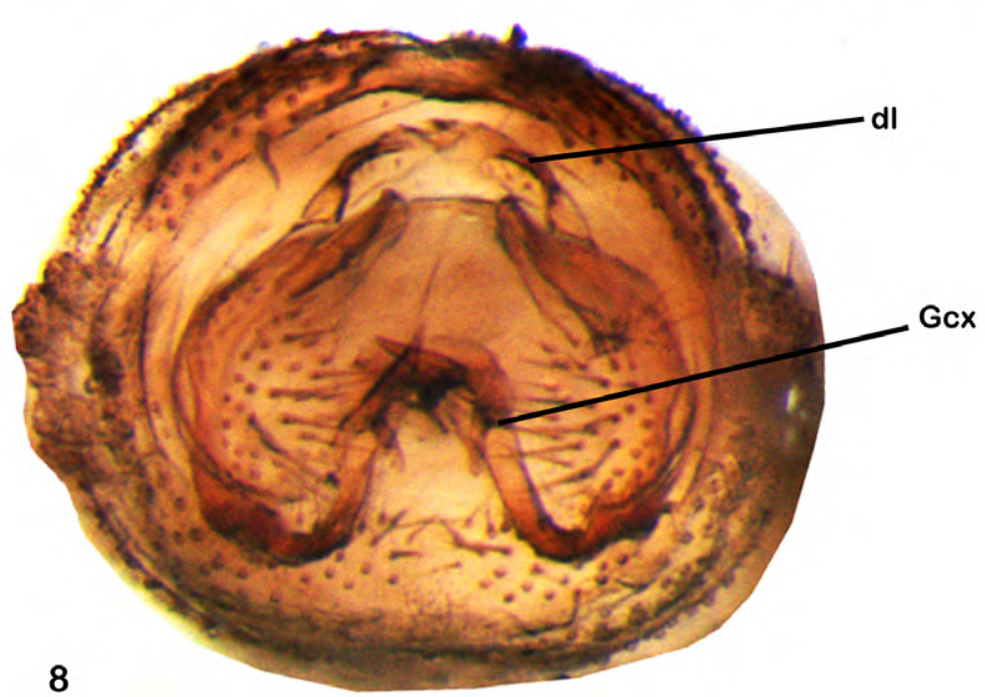

Figures 4-8. Male of Nallachius dicolor Adams, 1970 (Neuroptera: Dilaridae) from Jatobá, state of Pernambuco, northeast Brazil. 4-5: Abdominal apex, dorsal view. 6-7: Genitalia, lateral view. 8: Abdominal apex, caudal view. Gonocoxite (Gcx); dorsal lobe of ectoproct (dl); lateral projection of mediuncus (Imu); median lobe (MI). 


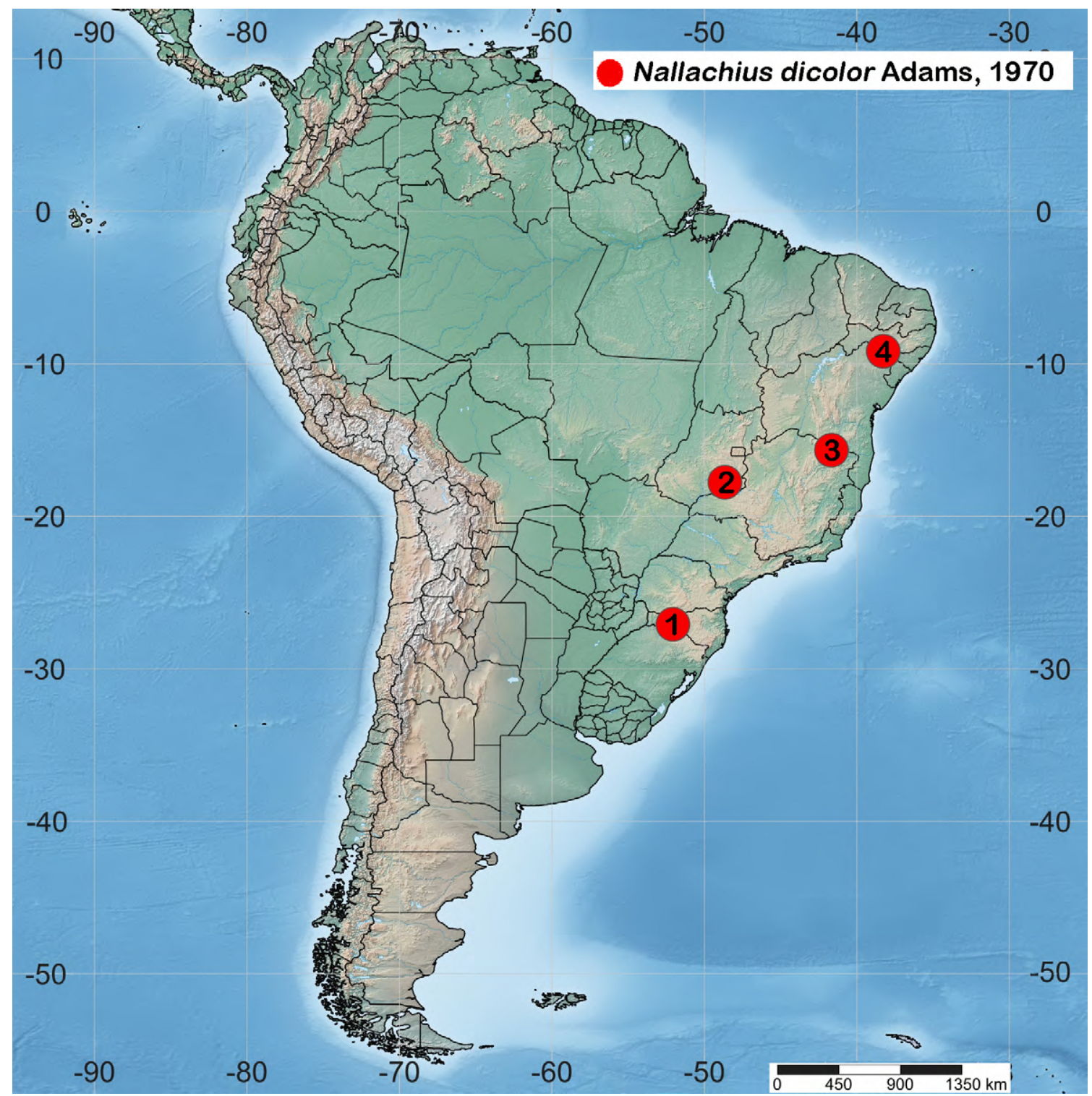

Figure 9. Geographic distribution of Nallachius dicolor Adams, 1970 (Neuroptera: Dilaridae). Nova Teutônia, state of Santa Catarina (1); Caldas Novas, state of Goiás (2); Berizal, state of Minas Gerais (3); Jatobá, state of Pernambuco (4).

using the Auto-Montage Pro v5.02.0096 software, with further editing using Adobe Photoshop CS4.

The identification of the specimen (Figures 1-8) was made using the key in Machado and Rafael (2010) and the original description of the species by Adams (1970). Identification was confirmed by Renato José Pires Machado. The specimen was deposited at the Museu de Zoologia da Universidade de São Paulo (MZUSP).

Nallachius dicolor differs from the other Brazilian Dilaridae species by the combination of the following characters: head pale with unmarked labrum, tubercles on anterior vertex larger than the two posterior ones; forewing with MP2 and $\mathrm{CuA}$ not fused and most distal costal cross veins unforked; dorsal lobes of ectoprocts approximated on midline; male genitalia with unforked median lobe (Figures 5-8), lateral projections of mediuncus slender-ligulate apically and gonocoxites lancet-shaped (Figures 4-8); dorsal plate of gonarcus absent (Adams 1970; Penny 1981; Machado and Rafael 2010).

Nallachius dicolor has a wide distribution in Brazil, occurring in the states of Santa Catarina, Goiás, Minas Gerais and Pernambuco (Figure 9). Martins and Amorim (2015) erroneously reported this species from Mato Grosso, as well as N. furcatus Machado \& Rafael, 2010 from Pernambuco. The current distribution of Brazilian species of Dilaridae is in Table 1.

The natural history and biology of Dilaridae are poorly understood, except for the immature stages of Nallachius americanus (McLachlan, 1881) whose larvae are found under the bark of recently dead trees (Quercus Linnaeus and Liriodendron Linnaeus) (Gurney 1947; MacLeod and Spiegler 1961; Penny 1981; Oswald 1998; Grimaldi and Engel 2005). More data about the species of this family are needed, in order to better understand their biology and biogeography. In this 
study we increase the knowledge about the distribution of Brazilian Dilaridae and thereby contribute to future biogeographic studies on this family. It is important to emphasize that $N$. dicolor occurs in northeastern Brazilian Caatinga, a region in which biodiversity is poorly studied.

\section{ACKNOWLEDGEMENTS}

We would like to thank Renato José Pires Machado for confirmation of the Dilaridae identification. CCM would like to thank Coordenação de Aperfeiçoamento de Pessoal de Nível Superior (CAPES) for financial support.

\section{LITERATURE CITED}

Acker, T.S. 1960. The comparative morphology of the male terminalia of Neuroptera (Insecta). Microentomology 24: 25-84.

Adams, P.A. 1970. A review of the New World Dilaridae. Postilla 148 $1-30$.

Governo do Estado de Pernambuco. 2015. Geografia. extensão territorial, população, densidade demográfica e localização do Município de Jatobá. Accessed at http://www.jatoba.pe.gov. br/a-cidade/geografia, 16 July 2015.

Grimaldi, D. and M.S. Engel. 2005. Evolution of the Insects. New York: Cambridge University Press. 755 pp.

Gurney, A.B. 1947. Notes on Dilaridae and Berothidae, with special reference to the immature stages of the Nearctic genera (Neuroptera). Psyche 54(3): 145-169. doi: 10.1155/1947/78317

Machado, R.J.S. and J.A. Rafael. 2010. Two new species of Dilaridae (Insecta: Neuroptera) with additional notes on Brazilian species. Zootaxa 2421: 61-68.

McLachlan, R. 1880. Occurrence of the neuropterous genus Dilar in South America. Entomologist's Monthly Magazine 17: 39. http://biodiversitylibrary.org/page/9277337

McLachlan, R.1881.ANorthAmerican species of Dilar. Entomologist's
Monthly Magazine 18: 55. http://biodiversitylibrary.org/page/ 9277677

MacLeod, E.G. and P.E. Spiegler. 1961. Notes on the larval habitat and developmental peculiarities of Nallachius americanus (MacLachlan) (Neuroptera: Dilaridae). Proceedings of Entomological Society of Washington 63: 281-286.

Martins, C.C. and D.S. Amorim. 2015. First record of pleasing lacewings (Neuroptera: Dilaridae) in São Paulo state, Brazil. Check List 11(1): 1538. doi: 10.15560/11.1.1538

Minter, L.R. 1986. The first record of Dilaridae (Neuroptera) from the Afrotropical Region. Journal of the Entomological Society of Southern Africa 49: 87-94.

Monserrat, V.J. 2005. Nuevos datos sobre algunas pequeñas familias de neurópteros (Insecta: Neuroptera: Nevrorthidae, Osmylidae, Sisyridae, Dilaridae). Heteropterus: Revista de Entomologia 5: 1-26. http://www.heteropterus.org/pdf/n5/Heteropterus_Rev_ Entomol_5_1-26.pdf

Oswald, J.D. 1998. Annotated catalogue of the Dilaridae (Insecta: Neuroptera) of the world. Tijdschrift voor Entomologie 141: 115-128.

Penny, N.D. 1981. Neuroptera of the Amazon Basin. Part 2. Dilaridae. Acta Amazonica 11: 383-390.

Zakharenko, A.V. 1991. Dva novykh vida semeistva Dilaridae (Neuroptera) iz V'etnama. Akademiia nauk SSSR, Zoologicheskii Zhurnal 70(9): 142-144.

Zhang, W., X.Y. Liu, H. Aspöck and U. Aspöck. 2014. Revision of Chinese Dilaridae (Insecta: Neuroptera) (Part II): Species of the genus Dilar Rambur from Tibet. Zootaxa 3878(6): 551-562. doi: 10.11646/zootaxa.3974.4.1

Author contributions: $C C M$ collected the data, identified the species and wrote the text; APA collected the data and wrote the text.

Received: 18 July 2015

Accepted: 28 April 2016

Academic editor: Aline Barcellos 